\title{
Building on Shaky Ground: Quality and Safety in China's Construction Industry in the Wake of the Wenchuan and Yushu Earthquakes
}

Michael Ting, (University of Melbourne)

\begin{abstract}
In China, development of building regulations has largely been motivated by a desire to maintain the booming construction industry which has sustained strong economic growth. As a result, the government has fallen behind on ensuring quality and safety in residential housing projects. The devastation left by the Wenchuan and Yushu earthquakes was a grim reminder of this. This essay aims to draw out some of the regulatory mistakes that have been made and proposes solutions to the issues raised. Regulators must refocus their attention on protecting the public and lay the legislative groundwork for healthy development in the sector.
\end{abstract}

Keywords: Wenchuan Earthquake, Quality and Safety Standards in China, Construction Law of the People's Republic of China

\section{Introduction}

The past 30 years has seen the ascendency of the Chinese economy to being one of the most watched and significant economies in the world. A large part of China's economic success has been attributed to the development of the property and construction industry (Chen 2010). However, in the wake of two devastating earthquakes in Wenchuan and Yushu, which led to the collapse of countless buildings, serious questions have been raised as to the adequacy of construction regulation in China.

This essay examines these questions and discusses some of the key deficiencies in the way construction practices are regulated in China. The earthquakes serve as a background to this discussion by focusing attention on the impact that deficient regulation has on people's lives and therefore my analysis will be primarily on residential construction. The rural location of the earthquake also provides the opportunity to discuss the impact of construction regulation outside of the urban setting, and how the differences in buildings and their construction methods are reflected in the relevant building codes. A technical analysis of seismic building codes on the adequacy of various seismic modelling methods is not the aim of this paper. Rather this essay aims to take a detailed look at the regulatory environment of residential construction specifically, and how these laws are enforced.

The structure of this discussion is as follows; Part II will provide some background to the development of China's construction industry, and canvass the current state of construction law in China. The main legislative instrument to be analysed will be the Construction Law of the People's Republic of China (1997) as well as various building codes that form the basis of residential construction in China. Part III is an analysis on some of the deficiencies in China's regulatory landscape. Two key failings are discussed; an inconsistent system of regulation; and a lack of adequate supervision to ensure proper enforcement of the law. Finally, Part IV proposes some changes to China's construction law, focusing on systemic and legislative reform. 


\section{The State of Construction Law in China}

\section{The Nature of China's Construction Industry}

At the turn of the 21st century, the construction industry had a significant effect on the growth of China, accounting for around 7 per cent of the country's gross domestic product ( $\mathrm{Li}$ et al 2003: 527). Total output of the construction industry grew at nearly 20 per cent annually between the years 2000 and 2003 ( $\mathrm{Li}$ et al. 2003, Biz China 2010). The strength and importance of the construction industry is relevant to our discussion for three main reasons.

First, a robust system of regulation facilitates sustainable growth by demanding high quality, efficiency and transparency. The Chinese government has recognised this and has repeatedly singled out the development and reform of construction regulation as the key factor for sustaining the growth of the construction industry. In a speech introducing a conference on building codes, the Vice Premier of China, Mr Zeng Peiyan, stated that construction investment was very important for China's economic growth and he hoped that China could improve construction standards and the legal system (National Work Conference for Fixed Construction Standards 2007).

Second, these figures demonstrate the size of the industry and therefore the corresponding enormity of the task of crafting laws which encompass the entire country. This task is made more complicated not only because China has such a vast population and landmass, but also because China is extremely diverse in climate, geology and hazard conditions.

Third, the rapid development of the construction market has meant that irregular practices have spread quickly and taken root in the culture of the industry. It is not uncommon for construction projects to be lubricated with kick backs and other gratuities (Hoenig 2009). Such wide-spread practice casts a long shadow. Irregular conduct invariably leads to poor build quality and dangerous defects. Persistent quality issues leads to dissatisfaction and lowers public confidence in building construction. The collapse of so many buildings when the Wenchuan earthquake struck is an unfortunate result of an industry that has been unregulated for the majority of its existence.

\section{China's Scheme of Regulation for Quality and Safety in the Construction Industry}

In order to maintain order and develop this vital industry, the National People's Congress of China (the 'NPC') promulgated the Construction Law of the People's Republic of China on 1 November 1997. This was the culmination of nearly 13 years of legislative drafting and over 20 years since China's open-door policy, which shifted the nation's communist economic model towards a market system. The passage of this law was particularly difficult because of the complexity of regulating the sprawling industry as well as defining the scope of application.

Although the complete scope of the Construction Law is contentious, especially in relation to specialised civil projects, it is generally accepted that the Construction Law regulates activities involving the construction of any kind of house building which means 'facilities that have a roof, beams [sic] posts, walls and a basement to form inner space to meet the needs of people for production and life' (Chen 2002: 277). Thus, the Construction Law represents the highest piece of legislation which governs the residential construction industry and will be the focus of our discussion.

The main objective of the Construction Law is to maintain order and ensure quality and safety for residential construction. Article 1 states:

This law is enacted for the purpose of tightening supervision over and administration of construction activities maintaining order of construction market, ensuring

Ting, M (2010) 'Building on shaky ground: Quality and safety in China's construction industry in the wake of the Wenchuan and Yushu earthquakes', Australasian Journal of Construction Economics and Building, 10 (3) 62-75 
construction quality and safety and promoting sound development of the construction industry.

To this end, the Construction Law prescribes three primary mechanisms to ensure compliance. First, all professionals engaged in construction activities are required to meet certain qualifications. Design and construction enterprises must only engage in construction activities within the scope permitted by their qualification grade (Construction Law 1997 art. 13). The second condition is that most construction projects require permission from the state prior to commencement of building works (Construction Law 1997 art. 7). Third, projects are generally required to be supervised (Construction Law 1997 art. 33).

The Construction Law sets up the general scheme of regulation for ensuring quality and safety in the residential construction industry but the details of acceptable construction practices are left to State safety standards (Construction Law 1997 art. 3). These State safety standards are the equivalent to Australian standards and operate to prescribe satisfactory materials, design and construction methodology. There are some 5000 engineering construction standards in China (National Work Conference for Fixed Construction Standards 2007), 503 of which relate to residential construction (Notice of the 2009 National Construction Standards, Quality, Supervision, Law Enforcement and Inspection Briefing 2009). The primary standard for residential housing is the Design Code for Residential Buildings 2003.

In addition to these standards, official government policy documents can prescribe further detail on building practices. These policy documents are issued on an ad hoc basis and are often in response to poor performance or public dissatisfaction. For example, in response to sub-par building standards revealed by a 2009 nationwide audit of building quality, the Ministry of Housing and Urban-Rural Development issued a notice prescribing specific procedures for project managers to follow (Notification of the Requirements for Acceptance of Good Quality Residential Household Projects 2009). The actual status of these policy documents is ambiguous, largely due to the fact that they are broad in nature and lack specific direction.

\section{Wenchuan, Yushu and Subsequent Developments}

During the years of rapid growth, regulators had little time to consider the adequacy of the laws which regulate this vital industry. The Chinese Government was forced to pause and think on this issue on 12 May 2008 when the most devastating earthquake since the founding of modern China struck Wenchuan in Sichuan province. Whilst it cannot be denied that the Wenchuan earthquake was severe - registering eight on the Richter Magnitude Scale - questions were raised both domestically and internationally as to whether there were sufficient measures in place that might have mitigated the impact of this disaster. Approximately 70000 people were killed in the disaster, mostly by collapsed buildings, and millions more were displaced from their homes (Shi 2008). Importantly, Sichuan is a largely rural province in the middle of China's landmass, with the majority of its population made up of migrant workers who work in the main cities on the east coast (China's Statistics on Urbanisation 2004). Such large loss of life, despite the relative sparseness of the area, gives an indication of the grim failures of building design and construction.

The ambit and adequacy of the quality assurance measures had never before been put to the test on a scale to that of the Wenchuan earthquake in 2008. The disaster highlighted some deficiencies in the system and swift government reform followed. The national code for the Seismic Design of Buildings (2001) was updated, additional laws were enacted to cope with earthquake and disaster mitigation and countless policy announcements pledged that lessons were learned.

Ting, M (2010) 'Building on shaky ground: Quality and safety in China's construction industry in the wake of the Wenchuan and Yushu earthquakes', Australasian Journal of Construction Economics and Building, 10 (3) 62-75 
Yet, in early 2010, a magnitude seven earthquake struck Yushu county in nearby Qinghai province killing over 2000 people (United States Geological Survey 2010). Far fewer deaths were reported in this disaster compared with the earthquake two years prior, however, the impact of the disaster should not understated. The Yushu epicentre was merely 600 kilometres from Wenchuan and despite the two years of frantic reform and seismic fortification, there were clearly persistent issues with the regulation of China's residential industry.

\section{Major Issues}

The primary aim of building codes is to protect the public and prevent loss of life (Merritt \& Ricketts 2000; Rules for Preparation of Construction Standards 1999). This means that buildings designed under the code should, at a minimum, not collapse, even if earthquake forces exceed design specifications (Merritt \& Ricketts 2000; Construction Law 1997 art. 60). Therefore, the extent of damage and loss of life in both earthquakes might lead us to presume that the Chinese building standards were inadequate to properly fulfil its function. Indeed, this was the call from many international observers in the immediate aftermath of the quake (Lee 2008). However, reports have since emerged that structures designed and built according to the relevant building standards performed surprisingly well under the pressure of the earthquakes (Miyamoto 2008). For example, a middle school built in 1996 before the implementation of the Construction Law and the code for the Seismic Design of Buildings (2001) suffered sudden collapse during the tremors of Wenchuan, but the primary school next door, built in 2007 and compliant with current design standards, remained standing with only minor damage (Miyamoto 2008). Some have even found that buildings in Wenchuan that complied with the prescribed building standards 'were able to resist shaking greater than what they were designed for.'(Paterson, Del Re \& Wang 2008: 4) In fact, experts have noted that China's building codes are generally on par with international standards (Australian Broadcasting Company 2008). This observation demonstrates that regulators in China have put in place adequate laws for the protection of the public. Yet the question remains as to why so many buildings collapsed in the two earthquakes.

The answer to this and why it is likely that buildings will continue to suffer from quality and safety issues in the future is that although the laws are adequate to meet the demands of an extraordinary disaster, laws are not being implemented adequately. This is either attributable to a lack of understanding on the part of builders and designers, or a lack of supervision to curb a culture of short-cuts and mismanagement.

\section{Incoherent Regulation}

\section{Proliferation of Building Regulation}

Building standards form the bulk of China's construction regulation. These safety standards ostensibly operate like standards in Australia in that they provide the detail on acceptable building practice which statutes lack. However, their actual function in China is ambiguous. This is because since the initiation of China's policy on standardisation through the Standardization Law of the People's Republic of China in 1988, there has been a massive proliferation of residential building standards at both the national and provincial level. The Wenchuan disaster accelerated this process. In the past five years alone, 1276 new construction standards were brought into force, bringing the number of national engineering construction standards to 4950 by the end of 2009 (National Work Conference for Fixed Construction Standards 2007). This staggering amount of regulation highlights the great potential for confusion of construction standards. Yet, it appears that the creation of new standards is seen as a mark of success for China, as officials have announced that formulation of these codes signifies significant progress for the sustainable and healthy development of the construction industry (National Work Conference for Fixed Construction Standards 2007). The large volume of standards, policy and other laws in the industry invariably results in an inconsistent regulatory message. This is particularly the case after the Wenchuan disaster, when officials scrambled to announce new measures. New laws

Ting, M (2010) 'Building on shaky ground: Quality and safety in China's construction industry in the wake of the Wenchuan and Yushu earthquakes', Australasian Journal of Construction Economics and Building, 10 (3) 62-75 
were implemented over the old with no guidance as to which to follow. For example, the Requirements for Acceptance of Good Quality Residential Household Projects was promulgated in 2009 in response to concerns raised since Wenchuan, however, the Regulations on the Quality of Construction Projects had already operated since 2000. Both laws are still effective and purport to ensure quality of residential construction through supervision. Yet they differ in the wording of similar provisions. In the older regulation, inspectors were expressly required to sample 'trial pieces and other relevant materials involved in structural security' (Regulations on the Quality of Construction Projects 2000 art. 31), but in the 2009 notice, inspectors are given a long list of areas to inspect, none of which relate to structural security (Requirements for Acceptance of Good Quality Residential Household Projects 2009 art. 2).

Clearly, the enthusiasm to regulate the industry has not been met with equal attention to consistency. The lack of consistency is a concern for ensuring wide-spread adherence to the building codes. Indeed, it is not argued that the standards created by regulators have been inadequate, rather that there has been no effort to making these standards easier to understand and implement by builders and designers. This is particularly a problem for the rural population, where houses are often erected by local builders who have little knowledge of the building standards and even less desire to read the multitude of standards that might be relevant for a project.

\section{Lack of Clear Hierarchy}

Another issue which affects the ability of contractors and designers to implement building standards is the absence of a clear legislative hierarchy. Whilst the Construction Law and national standards comprise the majority of the regulation, policy announcements often interpret these instruments to give further guidance on the provisions. However, policy announcements may originate from a number of different sources in the large bureaucracy that governs construction in China. The below flow-chart illustrates the multitude of sources for construction policy and regulation in China (Zuo \& Zillante 2007: 357):

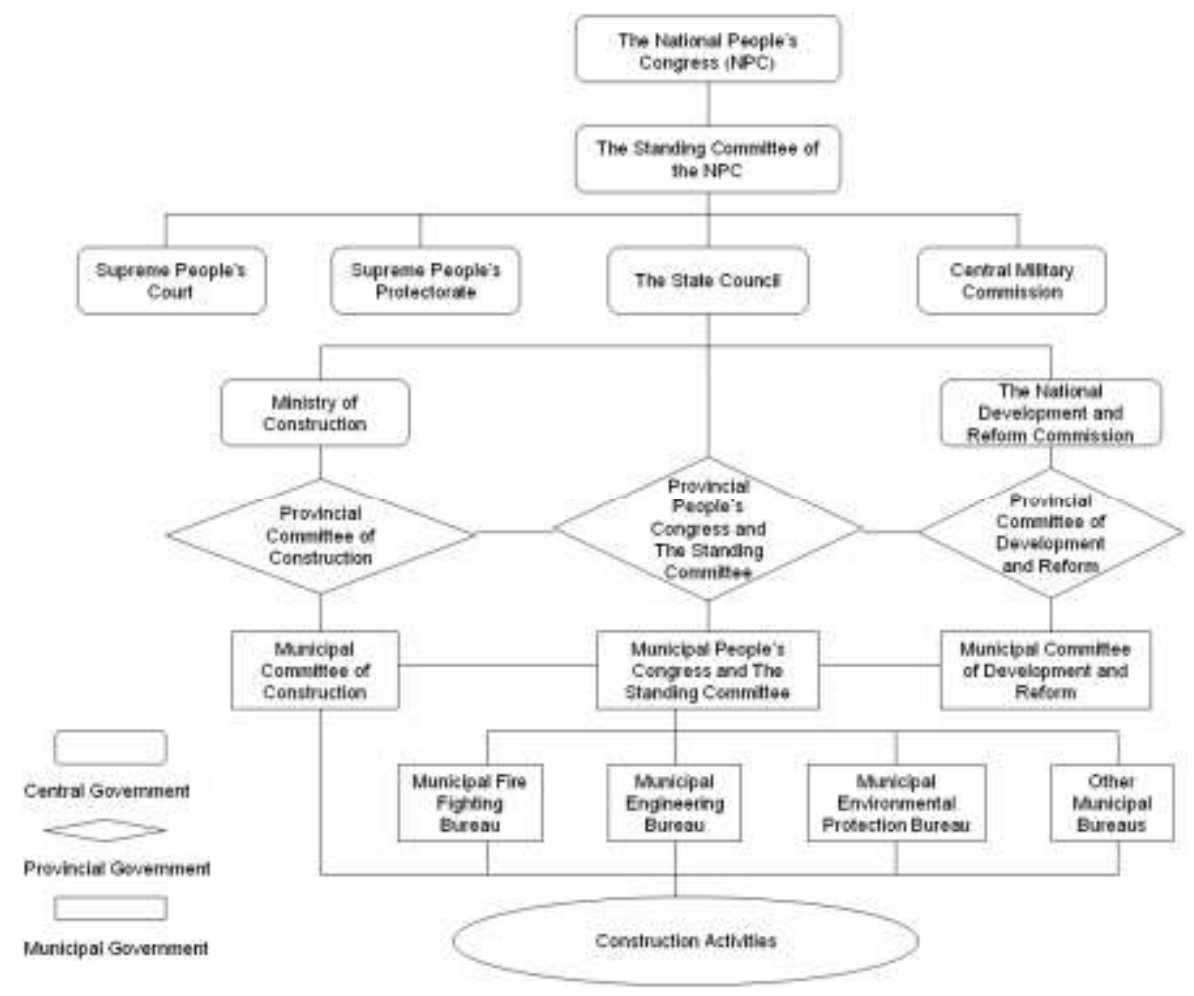

Ting, M (2010) 'Building on shaky ground: Quality and safety in China's construction industry in the wake of the Wenchuan and Yushu earthquakes', Australasian Journal of Construction Economics and Building, 10 (3) 62-75 
This diagram represents the different governmental departments that can influence the regulation of construction activities. Therefore, although the Ministry of Construction is generally responsible for controlling the industry, there is the potential for each department to issue separate policy announcements having ambiguous legislative force on the growing volume of building standards which regulate the industry.

\section{Enforcement Issues}

Despite some flaws in the way regulation is promulgated and formulated, the content of the laws themselves is generally considered to be adequate to meet reasonable demands. Yet, no matter how adequate the laws, the Wenchuan and Yushu disasters demonstrated that they were not being enforced. A number of factors have contributed to the failure of enforcement in the building industry. The phenomenal growth of China's economy has outstripped the capacity for the government to supervise construction projects. The sheer size and population diversity of the country further multiplies the task of enforcing the law. Moreover, China's construction sector has developed unregulated for a longer period than the Construction Law has been operative. Business practices proscribed by the Construction Law had already been established in the culture of the industry. In the mid-1990s some 63 per cent of all corruption cases investigated in China involved construction projects (Hoenig 2009: 2). Yet, despite these long-standing problems, China's legislative framework has failed to adequately address them.

Though the Construction Law provides for the supervision of construction projects ${ }^{1}$; enforcement is piecemeal and insufficient. Article 30 stipulates that

The State [shall] apply a system of supervision over construction projects. The State Council may define the construction projects over which supervision shall be enforced. (Emphasis added).

Herein lies the problem; whilst contractors and designers are required by law to adhere to the quality and safety provisions in the Construction Law and other instruments, there is no mandatory scheme of supervision to ensure compliance. Nor is there comprehensive regulation to specify which projects should be supervised. Some regulations suggest supervision shall be implemented for projects which are invested in by the government, state-owned enterprises and foreign capital (Notice on Launching the Work of Supervision of Construction 1988), whilst others require supervision of 'national key construction projects, large and medium scale projects of public utility...and projects built with the loans and assistance funds of the foreign governments or international organisations' (Regulations on the Quality of Construction Projects 2000 art. 12). The lack of compulsory supervision is not merely an oversight of the drafting committee; voluntary supervision is expressly stated in article 53 of the Construction Law:

Enterprises may, on a voluntary basis, apply for certification of quality assurance to the administrative department for supervision over...product quality.

The consequences of such a policy was seen when the Wenchuan earthquake hit in 2008. Anecdotal evidence of engineers who visited the scene reported how buildings built right next to each other, with the same orientation and similar design, met drastically different ends. Miyamoto (2009: 5), one of the first foreign engineers to visit the earthquake zone in Wenchuan, observed:

\footnotetext{
${ }^{1}$ Supervision is required by the government on certain projects. Supervisors/inspectors are certified according to national standards and graded according to their professional experience, facilities, number of personnel, equipment etc. They are not government employees but usually employees of a company engaged in inspection/supervisory services and hired by developers to supervise their project.
}

Ting, M (2010) 'Building on shaky ground: Quality and safety in China's construction industry in the wake of the Wenchuan and Yushu earthquakes', Australasian Journal of Construction Economics and Building, 10 (3) 62-75 
On an eerily, quiet, abandoned street, we come across a half collapsed, 5-story concrete apartment building. The corner of the structure totally collapsed into the street. It appears that the soft story columns failed and lost their capacity to support the structure above. Interestingly, immediately next door is an almost identical building with minor damage. Construction quality and possibly some vital structural details are the likely difference here.

Such quality and details were observed and enforced in the standing building, whilst were likely overlooked in the collapsed one. These stories suggest failure of appropriate supervision. Quality supervision which, if applied to the two buildings equally, might have saved the occupants of both buildings.

The extent of the supervision inadequacies was revealed in a nationwide survey conducted in 2009 where only 64 per cent of construction projects surveyed complied with the relevant laws, 32 per cent failed to meet minimum requirements in certain areas and 4 per cent of projects failed to satisfy any of the inspectors' standards (Notice of the 2009 National Construction Standards, Quality, Supervision, Law Enforcement and Inspection Briefing 2009). These figures might even be considered generous as the survey only inspected 90 of the major cities in China and did not survey rural areas; the areas which were hardest hit in both the Wenchuan and Yushu earthquakes. The survey underlines the lack of consistent enforcement of minimum quality standards during the construction of projects.

An additional failing in China's system of supervision is the limited scope of the supervisor's functions as stipulated by the Construction Law. Under Article 33, the project developer 'shall inform in writing...the items under supervision and the limits of power for supervision.' The supervisor therefore is to supervise only items of the project as instructed by the developer. Should the developer not want any attention to be drawn to a certain aspect of a project, the developer is at liberty to restrict access to the supervisor.

Furthermore, the role of the supervision unit is not solely focused on ensuring construction quality but also encompasses supervision over the 'construction period and [the project's] use of construction funds' (Construction Law 1997 art. 52). Therefore a supervision unit's role is diluted by having to engage in time and cost management, and its 'main' responsibilities may be even be circumscribed further by the project developer. Such provisions do not provide the adequate conditions for strict and wide-spread adherence to construction regulation.

\section{Suggested Reform}

The regulatory environment in the residential construction industry can make improvements to many of the identified issues. The Wenchuan and Yushu tragedies were unfortunate wake-up calls for change and the government has shown a willingness and enthusiasm for reform of the construction sector. Many of the new regulations that have been issued since 2008 have promoted the development of a higher level of building regulation (Law of the People's Republic of China on the Earthquake Prevention and Disaster Relief 2008 art. 65). The government even declared 2009 as quality and safety year. Despite China's many announcements renewing its commitment to ensuring that such disasters do not happen again, one cannot help but notice a pattern of reactionary regulation. As discussed in Part III, more laws, standards and policy announcements is not the solution to a crisis of implementation. Improving the implementation of the laws should be addressed by making sure builders and designers fully understand the standards expected of them and that there are adequate supervisory measures to ensure compliance with the regulations.

This problem should be met with two main changes: (i) institutional change to the way laws are formulated and promulgated to reduce the regulatory inconsistency; and (ii) tighter measures should be created for supervision units to ensure compliance with standards.

Ting, M (2010) 'Building on shaky ground: Quality and safety in China's construction industry in the wake of the Wenchuan and Yushu earthquakes', Australasian Journal of Construction Economics and Building, 10 (3) 62-75 


\section{The Need for Regulatory Consistency \\ Unification of Building Codes}

The rising volume of regulation surrounding the residential construction industry is a bewildering hurdle for builders, especially in rural areas, to overcome. However the greatest threat to robust regulation in the industry is the inevitable inconsistencies that such a proliferation of new laws will create. A prime example is the building regulations for the construction of aged care housing. The Ministry of Housing and Urban-Rural Development promulgated the Code for Design of Buildings for Elderly Persons in 1999, and in 2003 issued the Code for Design of Residential Building for the Aged to regulate the same area. Both codes are still effective, and this overlapping regulation is potentially a source of confusion for builders engaged in construction of aged care housing.

One solution to reducing the volume of laws and improving the consistency of the regulatory message would be to adopt a single building code which applies to residential construction in all provinces. The current residential building code only prescribes building standards for standard long-term dwellings (Design Code for Residential Buildings 2003 arts. 1-2), and should be expanded to at least include residential buildings for transient and special purpose housing including dormitories, kindergartens and aged-care facilities. This will require the various government departments which currently regulate the industry to work together to formulate a comprehensive and consistent building code.

A good model for China's reform is the Building Code of Australia ('BCA'), which is a twovolume code encompassing a wide range of building types. The BCA divides the different types of buildings into 10 classes and prescribes standards according to their purpose and characteristics. The first three classes relate to residential housing, including both long-term and transient dwellings (BCA 2009: 39-40). This does not merely mean that the various codes will be packaged together in the one document. Rather it will it will force the various government departments involved in construction management to work together to produce a unified regulatory message. This will reduce the overlapping of policy notices and conflicting interpretations. In addition, it will also eliminate the doubling-up of building codes that currently exist. Instances similar to the regulations for aged care housing can be avoided. Furthermore, by distilling the large volume of residential standards and codes into a single document, builders will have an easier time navigating the regulatory landscape. This will hopefully produce an environment where builders are fully aware of the responsibilities expected of them.

\section{Performance Oriented Codes}

In addition to unifying building regulation, the nature of the code itself can be improved. Current codes are drafted in a prescriptive manner such that the provisions require rigid adherence to certain building standards and practices. Deviation from these strict rules leaves open the possibility of civil and criminal penalties. Given China's population, climate and geological diversity, a nation-wide unified code with highly prescriptive provisions is likely to make adherence to the standard quite demanding. This is especially true for rural construction where builders might use materials and construction methods not outlined in a prescriptive code. Therefore, instead of formulating a code which specifies particular building practices, there should be a move towards a more performance oriented model. A performance code specifies the performance requirements, but leaves materials and methods for the designer to choose (Merritt \& Ricketts 2000: 37).

Typically, a performance code is structured in three parts characterised by three questions. The highest layer and first question is an objective statement, asking what is to be accomplished. The second layer is a functional statement which asks why the objective is to be accomplished. Level three are the performance requirements which outline how the functions and objectives are to be achieved. For example, in the area of structural security, the objective might be to 'safeguard people from injury caused by structural failure.' (BCA

Ting, M (2010) 'Building on shaky ground: Quality and safety in China's construction industry in the wake of the Wenchuan and Yushu earthquakes', Australasian Journal of Construction Economics and Building, 10 (3) 62-75 
2009 [B01]) The function of a building in this matter should be to 'withstand loads and other actions to which it may be reasonably subjected.' (BCA 2009 [BF1.1]) Some performance requirements could be to 'remain stable and not collapse' (BCA 2009 [BF1.2]). Note that the performance requirement does not prescribe a particular building solution; rather it asks the builder or designer to solve the problem. A code formulated in this way gives flexibility to the contractor to construct a building according to local specifications as long as it fulfils the performance requirements.

A criticism of performance codes is that they do not provide sufficient guidance as to actual building solutions. Performance codes are ostensibly of limited utility in a country like China with a large rural population whose building designers and contractors might have little concern for finding building solutions themselves. However, formulating a performance code does not necessarily preclude the code from providing suggestions on particular building solutions that would automatically satisfy the performance requirements of the code. For example, the BCA is a performance oriented code, but suggests 'deemed-to-satisfy' provisions which if followed would be automatically compliant with the performance requirements of the code (BCA 2009: 15-6). Therefore, structuring China's uniform building code with performance goals does not necessarily mean builders will forgo the quick and clear guidance of prescriptive codes. Instead, by adopting similar 'deemed-to-satisfy' provisions it will provide both a quick and flexible guide to the to the country's diverse construction industry. In fact, a performance code will not be a completely foreign concept to China's current regulation. Article 17 of the Rules for Preparation of Construction Standards (1999) expressly provides that codes should be formulated according to a three tiered structure similar to that of performance codes. Therefore, should the government adopt performance oriented codes, the emphasis of the rules will change, but the drafting process and structure of the codes will remain the same.

The result of formulating such a code would be a more consistent, accommodating and easy to understand law which would likely lead to an increase in the implementation of building standards. Making sure builders understand the code is but one part of the necessary reform required to ensure proper compliance with quality and safety standards. Indeed, if a unified performance code was to be adopted, greater supervision must be implemented to certify building practices not provided in the 'deemed-to-satisfy' provisions and enforce consistent and wide-spread compliance with the code.

\section{Enforcement Reform}

Strengthening the structure of regulation in China is a major step to ensuring higher quality and safer buildings. However, regardless of whether the government adopts a uniform building code in China, greater and more consistent enforcement will still remain a key issue. As mentioned in Part III, there are number of factors that has led to a crisis of law enforcement in China. A soaring economy has created a booming construction industry and gave incentives for irregular business practices. The strength of the sector has outpaced the government's capacity to maintain adequate supervision over construction projects. Whilst China might not want to restrict the growth of its economy for the sake of greater law enforcement, the government can impose better laws to reign in some of the detrimental practices that have taken root in the industry. Current legislative efforts have been weak, and despite rhetoric from leaders about improving supervision, no rigorous reforms have materialised. Three key legislative amendments must be made to strengthen the enforcement of building regulations.

First, the Construction Law must be amended to make supervision of construction mandatory for all residential projects. The Wenchuan and Yushu earthquakes demonstrated that the supervision of only select buildings is a policy which is highly prejudicial to residential and rural housing. At present, typically only buildings funded by the Chinese government are required to have supervision units present during construction (Regulations

Ting, M (2010) 'Building on shaky ground: Quality and safety in China's construction industry in the wake of the Wenchuan and Yushu earthquakes', Australasian Journal of Construction Economics and Building, 10 (3) 62-75 
on the Quality of Construction Projects art. 12). Such a policy is unsustainable for the future growth of the industry. As the construction sector develops, a greater proportion of building is likely to be undertaken by private enterprise, making the current legislative framework even more outdated. Without legislative measures to mandate supervision of construction work, there is a real risk that quality and safety will suffer.

The second amendment is to redefine the scope and powers of supervision units. Article 32 of the Construction Law currently requires supervision units to take on cost and time management responsibilities in addition to maintaining quality. Moreover, in article 33, developers can further circumscribe which areas of the project a supervision unit can inspect. These provisions must be removed to provide supervision units the independence to comment candidly on the true quality of construction work.

Third, in the wake of the Wenchuan and Yushu earthquakes, there should be express provision in the Construction Law for supervision units to inspect the structure of a building for seismic design compliance. China, by virtue of its size and geographical location, has a long history of high magnitude earthquakes. However, even after the two earthquakes, there is still no regulation which requires inspectors to specifically check for seismic code compliance.

To give force to these legislative amendments, the government must commit more to developing the supervision sector. Given the boom in the construction industry, the government should ensure that there is a corresponding demand for supervisors. This will give much needed incentive for people to enter the field and lessen the burden on government to micromanage the construction industry. This will require more training of supervisors. The government can further promote demand for supervisors by creating better information infrastructure for construction projects. If people are more aware of the quality and safety record of developers, there is a greater incentive for developers to maintain high standards. These are just a few suggestions that can further implement the overall objective of greater enforcement.

Encouraging supervision of construction projects is the primary tool for the Chinese government to ensure greater and more consistent enforcement of its laws. Amending the Construction Law to reflect its policy announcements should be the first step to laying the foundation to better quality and safety for residential property.

\section{Conclusion}

The construction industry has been a large part of China's economic success. However, the speed of growth for the sector has outpaced the regulatory framework. As a result, there are fundamental legal issues that provide cause for concern about the safety and quality of buildings, especially for rural housing. These concerns were fully realised in two major earthquakes in 2008 and 2010. The disasters highlighted serious problems in the way building regulations were formed and promulgated. Inconsistencies and a lack of legislative hierarchy made it difficult to decipher which standards to follow. Existing laws which provided for supervision of construction projects failed to consistently enforce quality and safety standards. Although the government has acted swiftly to enact new laws to meet the challenges revealed by the two earthquakes, there needs to be a paradigm shift in their approach to regulation. Instead of promulgating volumes of prescriptive rules on building design, there should be a concerted effort to unify standards. Key legislation needs to be updated to reflect the changing construction industry and a greater focus needs to be placed on independent supervision of projects. Wenchuan was an unfortunate wakeup call for an overzealous industry and a government comfortable with the fruits of an economic boom. There needs to be a refocusing of priorities on quality and safety of occupants. Of course implementing the changes outlined here will not immediately improve the quality and safety of residential construction, but they will at least lay the foundation for the healthy development of China's construction industry.

Ting, M (2010) 'Building on shaky ground: Quality and safety in China's construction industry in the wake of the Wenchuan and Yushu earthquakes', Australasian Journal of Construction Economics and Building, 10 (3) 62-75 


\section{Acknowledgement}

This author wishes to thank Mr Matthew Bell for his comments, guidance and support in helping to get this article written.

\section{Bibliography}

Australian Broadcasting Company (2008) 'Spotlight on China's Building Codes' Asia Pacific Focus, 25 May 2008

AS 1170, Standards Australia

Biz China (2010) The Tenth Five-Year Plan of the Construction Industry, Newspaper, China Daily, 28 May 2010, <http://bizchina.chinadaily.com.cn/guide/industry/industry5.htm>

Builders will be Jointly and Severally liable for the Collapse of the Construction Unit (2009) Ministry of Housing and Urban-Rural Development of the People's Republic of China (MOHURD), News release, 25 December 2009

Building Code of Australia (2009) Australian Building Codes Board

Chen, Z. G. (2002) 'A Comparison between the Construction Law of China and the Building Control Act of Singapore', Construction Law Journal, 18(4), 275-90

China National Accreditation Service for Conformity Assessment Website <http://eng.cnas.org.cn/index.htm1>

China's Statistics on Urbanisation (2004)《中国统计摘要》Bureau of Urban and Rural Population 2004

Chinese Government's Official Web Portal Website <http://english.gov.cn/>

Chinese Ministry of Housing and Urban-Rural Development Website $<$ http://www.mohurd.gov.cn>

Ching, F. and Winkel, S. (2009) Building Codes Illustrated: A Guide to Understanding the 2009 International Building Code, $3^{\text {rd }}$ edition, International Code Council

Code for Design of Buildings for Elderly Persons (1999) 《老年人建筑设计规范》 (JGJ12299) (People's Republic of China) Ministry of Construction

Code for Architectural Design of Cinema (2008) (JGJ58-2008) (People's Republic of China).

Code for Design of Detention Houses (2007) 《拘留所建设标准》 (JGJ127-2000) (People's Republic of China) Ministry of Housing and Urban-Rural Development of the People's Republic of China (MOHURD), 27 February 2007

Code for Design of Funeral Parlor Buildings (2000) (JGJ124-99) (People's Republic of China).

Code for Design of Residential Building for the Aged (1999) 《老年人居住建筑设计标准》 (GB/T50340-2003) (People's Republic of China) Ministry of Construction

Construction Law of the People's Republic of China (1997) 《中华人民共和国建筑法》 (People's Republic of China) National People's Congress, Order No 91, 1 November 1997 ('Construction Law')

Construction Supervision (2008) 《建设工程监理》(Statistical Bulletin for 2007, Ministry of Housing and Urban-Rural Development of the People's Republic of China, 24 June 2008)

Declaration of 2008 on the Development of Engineering Construction Standards, Amendments to the Notification Plan (2007) 《关于申报2008年度工程建设标准制订、

修订项目计划的通知》 (People's Republic of China) The People's Republic of China Ministry of Construction Office, 19 November 2007

Ting, M (2010) 'Building on shaky ground: Quality and safety in China's construction industry in the wake of the Wenchuan and Yushu earthquakes', Australasian Journal of Construction Economics and Building, 10 (3) 62-75 
Design Code for Residential Buildings (2003) 《住宅设计规范》(GB50096-1999) (People's Republic of China) Ministry of Construction, 24 April 2003

Design Code for Sports Building 2003 (JGJ31-2003) (People's Republic of China)

Guo, Y. (2009) 'Quality in the National Standardization for Safety in Construction', Speech delivered onsite at Ministry of Housing and Urban-Rural Development of the People's Republic of China, 4 December 2009

Hageman, R. (1983) 'An Assessment of the Value of Natural Disasters Damage Reduction in Dwellings Due to Building Codes: Two Case Studies', Natural Resources Journal, 23, $531-48$

Hoenig, J. (2009) 'Projects in China Need Vigilance' Engineering News Record, 263(19), 2

International Disaster and Risk Conferences Website <http://www.idrc.info>

Law of the People's Republic of China on the Earthquake Prevention and Disaster Relief (2008), (People's Republic of China) National People's Congress, Order No 7, 27 December 2008

Lee, D. (2008) 'Building Codes Not Set in Stone', Los Angeles Times (online), 14 May 2008 < http://articles.latimes.com/2008/may/14/world/fg-construct14>

Li et al. (2003) 'China Statistical Yearbook 2003' (Statistical Yearbook No 22, National Bureau of Statistics of China, 2003) 527

Merritt, F. and Ricketts, J. (eds) (2000) Building Design and Construction Handbook, $6^{\text {th }}$ edition, McGraw-Hill

Miyamoto, H. K. (2008) 'Sichuan Earthquake Disaster Chronicle: Through the Eyes of the First Foreign Engineers Onsite' <http://www.miyamotointernational.com/pdf_files/

2008\%20Sichuan\%20Earthquake\%20Disaster\%20Chronicle.pdf>

Museum of Science and Technology Building Standards (2007)《科 学技术馆建设标准》(People's Republic of China) The People's Republic of China Ministry of Construction, 27 August 2007

National Project Construction Standardization Information Network Website $<$ www.ccsn.gov.cn $>$

National Work Conference for Construction Standards (2007)

《中华人民共和国住房和城乡建设部》(People's Republic of China) Ministry of Housing and Urban-Rural Development of the People's Republic of China (MOHURD), 3 December 2007

National Work Conference for Fixed Construction Standards (2007)

《全国工程建设标准定额工作会》Ministry of Housing and Urban-Rural Development of the People's Republic of China (MOHURD), News Release, 3 December 2007

Nelson, A. (2010) 'US Engineers Study Chile Earthquake to Bolster California Building Codes' The Christian Science Monitor (online), 2 April 2010

News Release on Building Seismic Evaluation Standards and Technical Specification for Seismic Reinforcement (2009)《关于批准发布《公安派出所建设标准》的通知》(People's Republic of China) The People's Republic of China Ministry of Housing and Urban Engineering Quality Safety Supervision Division, 1 July 2009

Notice for the Declaration of the Year 2008 as the Year for Development of Engineering Construction Standards (2007)

《关于申报2008年度工程建设标准制订、修订项目计划的通知》The People's Republic of China Ministry of Construction Office, 19 Nov 2007

Notice of the 2009 National Construction Standards, Quality, Supervision, Law Enforcement and

Inspection

Briefing

(2009)

Ting, M (2010) 'Building on shaky ground: Quality and safety in China's construction industry in the wake of the Wenchuan and Yushu earthquakes', Australasian Journal of Construction Economics and Building, 10 (3) 62-75 
《关于2009年全国建设工程质量监督执法检查情况的通报》Ministry of Housing and UrbanRural Development of the People's Republic of China (MOHURD), 29 December 2009

Notice on Launching the Work of Supervision of Construction (1988) 《关 于开展建设监理工作的通知》The People's Republic of China Ministry of Construction Office, 25 July 1988

Notification on Immediate Safety Inspection of Construction Works (2010) 《关于立即开展建筑施工安全生产大检查的通知》Ministry of Housing and UrbanRural Development of the People's Republic of China (MOHURD), 6 April 2010

Notification on Quality Residential Projects (2007) 《关于做好住宅工程质量分户验收工作的通知》The People's Republic of China Ministry of Construction, 27 August 2007

Notification of the Requirements for Acceptance of Good Quality Residential Household Projects (2009) 《关于做好住宅工程质量分户验收工作的通知》Ministry of Housing and Urban-Rural Development of the People's Republic of China, Order No. 291, 22 December 2009

Opinions on Launching Special Rectification Work to Address the Major Problems in the Engineering and Construction Sector (2009) (People's Republic of China) General Office of State Council, Order No. 27, 9 July 2009

Paterson, Emily, Del Re, Domenico \& Wang, Zifa, (2008) The 2008 Wenchuan Earthquake: Risk Management Lessons and Implications, Discussion Paper, Risk Management Services

Police Station Construction Standards (2007) 《公安派出所建设标准》 (JGJ127-2000) (People's Republic of China) Ministry of Housing and Urban-Rural Development of the People's Republic of China (MOHURD), 27 June 2007

Provisions on the Administration of the Qualification of Enterprises for Survey and Design of Construction Projects (2001) 《建设工程勘察设计企业资质管理规定》Ministry of Construction, 25 July 2001

Regulations of the People's Republic of China on Certification and Accreditation (2003) (People's Republic of China) State Council, Order No 390, 20 August 2003

Regulations on Administration of Survey and Design of Construction Projects (2005) (People's Republic of China) State Council, Order No 293, 25 September 2005

Regulations on the Quality of Construction Projects (2000) (People's Republic of China) State Council, 30 January 2000

Reuben, Richard, (1994) 'Picking up the Pieces: Natural Disasters Shatter Insurance Rules', American Bar Association Journal, 80, 79

Rules for Preparation of Construction Standards (1999) 《工程建设标准编写规定》(People's Republic of China) Ministry of Housing and Urban-Rural Development of the People's Republic of China (MOHURD)

Seismic Design of Buildings (2008) 《建筑抗震设计规范》 (GB50011-2008).

Shi, P.J. (2008) 'China Wenchuan Earthquake Disaster (May 12 2008) and its Loss Assessment', International Disaster and Risk Conference, 29 August 2008, Davos Switzerland, 1-73. <http://www.idrc.info/userfiles/image/presentations2008/Shi_Peijun_ China_Wenchuan_Earthquake_Disaster.pdf>

Standardisation Law of The People's Republic of China (1988) 《中华人民共 和国标准化法》 (People's Republic of China) National People's Congress, 29 December 1988

Ting, M (2010) 'Building on shaky ground: Quality and safety in China's construction industry in the wake of the Wenchuan and Yushu earthquakes', Australasian Journal of Construction Economics and Building, 10 (3) 62-75 
Technical Specification for Seismic Strengthening of Buildings (2009) 《中华人民共和国行业标准: 建筑抗震加固技术规程》Ministry of Housing and Urban-Rural Development of the People's Republic of China (MOHURD), 16 June 2009

United States Geological Survey (2010), Magnitude 6.9 - SOUTHERN QINGHAI, CHINA (14 April 2010) United States Geological Survey <http://earthquake.usgs.gov/earthquakes/recenteqsww/Quakes/us2010vacp.php\#summary>

Wang Y. (2004) 'Comparison of Seismic Actions and Structural Design Requirements in Chinese Code GB 50011 and International Standard ISO 3010', Earthquake Engineering and Engineering Vibrations, 3, 1

Weller, Richard, (2005) 'AS 1170.4 Earthquake Actions in Australia: Worked Examples', Conference on Earthquake Engineering in Australia, The Australian Earthquake Engineering Society, 2005, Albury. <http://www.aees.org.au/Proceedings/2005_Index.pdf>

Wenchuan Earthquake Restoration and Reconstruction Ordinance (2008) 《汶川地震灾后恢复重建条例》 (People's Republic of China) State Council, Order No 526, 4 June 2008

Wu Y. and Wang S. (2009) 'Enlightenments of 512 Wenchuan Earthquake', Wenchuan Earthquake, the Path Forward, International Disaster and Risk Conference, 13-15 July 2009, Chengdu<http://www.idrc.info/userfiles/file/archive/2009/presentations/Wu_Yaoqiang_ Wang_Shaoyu_IDRC_Chengdu_2009.pdf>

Yushu (2010) Xinhuanet <http://www.qh.xinhuanet.com/yushu/>

Zhen, G. R. (2009) 'Developers of Buildings which Collapse Causing Injury and Death will be Jointly and Severally Liable', Newspaper, Xinhua, 22 December 2009

Zhu, I. (2006) 'China's Real Estate Investment Passes 5 Trillion Yuan mark', Newspaper, Xinhua (online), 30 January 2006 < http://english.gov.cn/2006-01/30/content_175605.htm>

Zuo, J. and Zillante, G. (2007) 'Building Surveying in China - Lessons learned from Australia', Australian Institute of Building Surveyors Conference, November 2007, Adelaide Australia, 351-66 